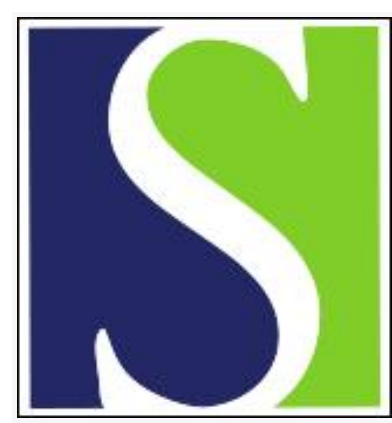

Scand J Work Environ Health 1981;7(1):31-37

https://doi.org/10.5271/sjweh.2569

Issue date: Mar 1981

Changes in rat liver microsomal cytochrome P-450 and enzymatic activities after the inhalation of $n$-hexane, xylene, methyl ethyl ketone and methylchloroform for four weeks.

by Toftgård R, Nilsen OG, Gustafsson J-A

Key terms: benzo(a)pyrene metabololism; enzymatic activity; induction; inhalation; methyl ethyl ketone; methylchloroform; microsomal cytochrome P-450; n-hexane; organic solvent; rat; rat liver; rat liver microsomal cytochrome P-450; steroid metabolism; xylene

This article in PubMed: www.ncbi.nlm.nih.gov/pubmed/7313607

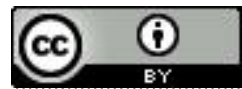




\title{
Changes in rat liver microsomal cytochrome P-450 and enzymatic activities after the inhalation of $n$-hexane, xylene, methyl ethyl ketone and methylchloroform for four weeks
}

\author{
by Rune Toftgård, BSc, ${ }^{1,2}$ Odd G Nilsen, PhD, , 3 Jan-Åke Gustafsson MD, PhD ${ }^{2}$
}

\begin{abstract}
TOFTGÅRD R, NILSEN OG, GUSTAFSSON J-A. Changes in rat liver microsomal cytochrome P-450 and enzymatic activities after the inhalation of n-hexane, xylene, methyl ethyl ketone and methylchloroform for four weeks. Scand $j$ work environ health 7 (1981) 31-37. Groups of Sprague-Dawley rats were exposed, by inhalation, to n-hexane $\left(900 \mathrm{ppm}, 3,240 \mathrm{mg} / \mathrm{m}^{3}\right)$, xylene $\left(600 \mathrm{ppm}, 2,625 \mathrm{mg} / \mathrm{m}^{3}\right)$, methyl ethyl ketone (800 ppm, $\left.2,345 \mathrm{mg} / \mathrm{m}^{3}\right)$ and methylchloroform $\left(800 \mathrm{ppm}, 4,345 \mathrm{mg} / \mathrm{m}^{3}\right)$ for four weeks. Increased liver weights and liver to body weight ratios were observed for all the solvents except $\mathrm{n}$-hexane. An increased in vitro formation of certain metabolites of all the investigated substrates was found only in the rats exposed to xylene. The in vitro microsomal metabolism of biphenyl, benzo(a)pyrene, 4-androstene-3,17-dione and $5 \alpha$-androstane$3 \alpha, 17 \beta$-diol in combination with sodium dodecyl sulfate-polyacrylamide gel electrophoresis showed that $n$-hexane was without effect on rat liver microsomal cytochrome P-450 and that methyl ethyl ketone and methylchloroform depressed the formation of two metabolites of androstenedione but did not alter the concentration of cytochrome P-450 under the experimental conditions used. Xylene was shown to be a phenobarbital-like inducer of rat liver microsomal cytochrome P-450.
\end{abstract}

Key terms: benzo(a)pyrene metabolism, induction, organic solvents, steroid metabolism.

Organic solvents are of great interest in the field of occupational health because of their frequent use in different types of industries.

It is now evident that effects such as hepatotoxicity and carcinogenicity are the results of metabolic activation occurring in the body. This phenomenon has been

1 Department of Pharmacology, Karolinska Institute, Stockholm, Sweden.

2 Department of Medical Nutrition, Karolinska Institute, Stockholm, Sweden.

3 Department of Pharmacology and Toxicology, University of Trondheim, Region Hospital, Trondheim, Norway.

Reprint requests to: Rune Toftgård, Department of Pharmacology, Karolinska Institute, Box 60 400, S-104 01 Stockholm, Sweden. shown for the hepatotoxicity and carcinogenicity of carbon tetrachloride, chloroform, and trichloroethylene $(2,18,30)$, the carcinogenicity of dioxane (33), the hepatotoxicity of carbon disulfide $(5,6,17)$, the leukemogenic effect of benzene (25), and the neurotoxicity of n-hexane and methyl n-butyl ketone $(4,27)$.

The enzyme system responsible for such activation through the formation of epoxides or other reactive metabolites is, in most cases, the one dependent on liver microsomal cytochrome P-450. The activity of this enzyme system, which consists of separate isoenzymes with different substrate specificities $(12,31)$, can be modulated by exogenous factors, including exposure to organic solvents. This modula- 
tion may lead to an altered susceptibility to the toxic effects of the solvent itself or to other environmental contaminants. An inducing effect on liver microsomal cytochrome $\mathrm{P}-450$ in rats has been shown after the inhalation of methylchloroform, benzene, carbon tetrachloride, and trichloroethylene $(10,20)$. On the other hand, both methylchloroform and carbon tetrachloride have been reported to decrease the liver microsomal content of cytochrome P-450 when administered intragastrically $(28,32)$, and this finding underlines the importance of using relevant administration routes in the evaluation of the biological effects of hydrocarbon solvents.

The present study was undertaken to investigate the effect of four commonly used hydrocarbon solvents with widely different chemical structures, $n$-hexane, $x y-$ lene, methyl ethyl ketone and methylchloroform, on the liver microsomal cytochrome P-450 enzyme system in the rat after inhalation. Changes in the different forms of cytochrome $\mathrm{P}-450^{4}$ and in the in vitro microsomal metabolism of biphenyl, benzo(a)pyrene, and the steroids 4-androstene-3,17-dione and $5 \alpha$-androstane- $3 \alpha$, $17 \beta$-diol were investigated.

\section{Material and methods}

\section{Animals and experimental design}

Male Sprague-Dawley rats weighing about $300 \mathrm{~g}$ were obtained from Anticimex (Sweden). The rats were kept in cages $5 \mathrm{~d}$ prior to treatment. They had free access to water and food and were kept in a room with controlled temperature and light (14 $h$ light - $10 \mathrm{~h}$ dark).

Groups of four rats were exposed during the light period of the day to solvent vapors [n-hexane $910 \mathrm{ppm} \pm 240$ ( $\pm \mathrm{SD}$ ) $\left(3,276 \pm 864 \mathrm{mg} / \mathrm{m}^{3}\right)$ and xylene $630 \mathrm{ppm}$ \pm 170 ( $\pm \mathrm{SD})\left(2,756 \pm 744 \mathrm{mg} / \mathrm{m}^{3}\right)$ in one experimen't and methyl ethyl ketone 760

4 The different cytochromes are referred to on the basis of the species, tissue, subcellular fraction, and molecular weight of the subunit as characterized by sodium dodecyl sulfatepolyacrylamide gel electrophoresis. Thus, RLvMc P-45050 denotes rat liver microsomal cytochrome P-450 with a subunit molecular weight of about 50,000 . $\mathrm{ppm} \pm 200 \quad$ (士 SD) $\left(2,229 \pm 587 \mathrm{mg} / \mathrm{m}^{3}\right)$ and methylchloroform 820 ppm \pm 130 ( $\pm \mathrm{SD})\left(4,451 \pm 706 \mathrm{mg} / \mathrm{m}^{3}\right)$ in another experiment] $6 \mathrm{~h}$ each day, $5 \mathrm{~d} /$ week, during four weeks. Control groups were exposed to circulating air only. The animals were killed by decapitation on the morning of the day after the last exposure. No food or drinking water was offered during the exposures. Only water was allowed during the $24 \mathrm{~h}$ preceding sacrifice.

\section{Inhalation exposure}

The rats were exposed in a glass desiccator fitted with inlet and outlet tubing. The volume of the desiccator was 211 , and an air flow of $8 \mathrm{I} \cdot \mathrm{min}^{-1}$ was maintained during the exposure. The desired composition of the exposure atmosphere was obtained by the mixing of measured portions of air and saturated solvent vapor. Every $2 \mathrm{~h}$ the exposure level was monitored from $0.2-\mathrm{ml}$ air samples taken in the animal's breathing zone with a prewarmed gastight syringe. These samples were injected into a gas chromatograph (Varian Aerograph Series 1400). A calibration curve was constructed with the use of gas standards containing known concentrations of the solvent.

\section{Preparation of liver microsomes}

Rat liver microsomes were prepared as previously described (31). The microsomes were suspended and diluted in a $0.05 \mathrm{MI}$ potassium buffer, $\mathrm{pH}$ 7.4, containing $10^{-4} \mathrm{M}$ EDTA (ethylenediaminetetraacetate) to a final concentration of about 30 $\mathrm{mg}$ of microsomal protein per milliliter. The protein concentration was determined by the method of Lowry (16), bovine serum albumin being used as the standard.

\section{Microsomal enzyme assays}

All enzyme assays were performed with freshly prepared microsomes. The total concentration of cytochrome P-450 was determined from the reduced carbon monoxide difference spectrum (21).

The assays of the biphenyl and the benzo(a)pyrene hydroxylase activities were performed as described elsewhere (31). In the high-pressure liquid chromatographic 
separation of benzo(a)pyrene metabolites, phenol fraction I and phenol fraction II were eluted with the same retention times as 9-hydroxy- and 3-hydroxy-benzo(a)pyrene. Incubations with $4-\left(4-{ }^{14} \mathrm{C}\right)$ androstene-3,17-dione and $5 \alpha\left(4-{ }^{14} \mathrm{C}\right)$ androstane$3 \alpha, 17 \beta$-diol were performed as described earlier $(3,7)$.

\section{Sodium dodecyl sulfate polyacrylamide gel electrophoresis}

The liver microsomes were diluted to a concentration of $1 \mathrm{mg}$ of protein per milliliter in $0.05 \mathrm{M}$ sodium phosphate buffer, $\mathrm{pH} 7.4$, containing $10^{-4} \mathrm{M}$ EDTA. The microsomal suspensions were treated with sodium dodecyl sulfate (SDS) $[150 \mathrm{mg} / \mathrm{mg}$ of protein $(0.5 \mathrm{mmol} / \mathrm{mg}$ of protein $)]$ and $\beta$-mercaptoethanol $[75 \mathrm{mg} / \mathrm{mg}$ of protein (1.0 $\mathrm{mmol} / \mathrm{mg}$ of protein)]. Electrophoresis was performed on slab gels (model 220 Dual Vertical Slab Gel Electrophoresis Cell, BIO-RAD Laboratories, USA) with the use of the discontinuous buffer system of Laemmli (14). The slab gels contained $7.5 \%$ acrylamilde in the separating gel and had the dimensions $140 \mathrm{~mm}$ (migration distance) $\times 100 \mathrm{~mm} \times 0.75 \mathrm{~mm}$ (thickness). Twenty sample wells were loaded with $5 \mu \mathrm{g}$ of protein each; $5 \mathrm{~mA}$ was applied per gel during stacking and $10 \mathrm{~mA}$ per gel during separation. As judged from the mobilities of the standard proteins phosphorylase B (mol wt 94,000), bovine serum albumin (mol wt 68,000), ovalbumin (mol w't 45,000), and carbonic anhydrase (mol wt 30,000 ), the resolution obtained during electrophoresis was sufficient to distinguish differences of 500 in the apparent molecular weights of the different types of liver microsomal cyitochrome P-450. The gels were stained for protein at $60^{\circ} \mathrm{C}$ with $0.25 \%$ Coomassie brilliant blue R-250 in water:ethanol:acetic acid (5:5:1) for $20 \mathrm{~min}$ and destained overnight at the same temperature in acetic acid:ethanol:water (1.5:1:17.5).

The qualitative identification, based on heme staining, of four different protein bands, induced by either phenobarbital or 3-methylcholanthrene, as cytochrome P450s (RLvMc P-450 RLvMc P-450 55 and RLvMc P-450 $0_{58}$ ) has been described elsewhere (31). Relative quantitation of the amount of protein in the different bands was performed by densitometric scanning on a Beckman scanning densitometer model R-112 at $500 \mathrm{~nm}$ after the gels had been stained with Coomassie brilliant blue R-250. A linear relationship between peak area and the amount of protein applied has been reported earlier (19).

\section{Statistics}

Student's t-test was used, and p-values of less than 0.05 were considered significant.

\section{Chemicals}

The following chemicals were purchased: 2-hydroxybiphenyl, 4-hydroxybiphenyl, benzo(a)pyrene, and $5 \alpha$-androstane- $3 \alpha, 17 \beta$ diol from the Sigma Chemical Co, St Louis, LA, USA; ethyl methyl ketone analytical grade (ag) and n-hexane (ag) from E Merck, Darmstadt, Federal Republic of Germany; xylene from Aristar, BDH, Chemicals Lit, Poole, England; 1,1,1-trichloroethane from Fisher Scientific Co, Fair Lawn, NJ, USA; bovine serum albumin ( $\mathrm{Fr}, \mathrm{V})$ from Miles Laboratories Ltd, Stokes Poges, England; biphenyl from Merck-Schucardt, München, Federal Republic of Germany; 3-hydroxybiphenyl from ICN Pharmaceuticals Inc, Plainview, NY, USA; [G-' $\left.{ }^{3} \mathrm{H}\right]$ benzo(a)pyrene (specific activity $26 \mathrm{Ci}$ per mmol) and 4$\left(4-{ }^{14} \mathrm{C}\right)$ androstene-3,17-dione (specific activity $0.06 \mathrm{Ci}$ per $\mathrm{mmol}$ ) from Radiochemical Centre, Amersham, England; and reference benzo(a)pyrene metabolites from IIT Research Institute, Chicago, IL, USA. The purity of the organic solvents was determined by gas chromatography. Xylene contained $23 \%$ ethylbenzene, $2 \%$ o-xylene, $64.5 \%$ m-xylene, $10 \%$ p-xylene, and $0.5 \%$ toluene. The level of benzene contamination was 4 ppm; 11 ppm of 1,1,2-trichloroethane was found in the methylchloroform.

\section{Results}

Of the organic solvents investigated, only xylene significicantly impaired the growth of the rats during the four weeks' exposure $[35 \pm 3 \mathrm{~g}( \pm \mathrm{SD})$ increase against $61 \pm 2 \mathrm{~g}$ for the control group].

The effects on liver weight and the total concentration of liver microsomal cyto- 
chrome P-450 are summarized in table 1. Significantly increased liver weights and liver to body weight ratios were observed after exposure to all the solvents studied except $\mathrm{n}$-hexane. Xylene exposure caused a $20 \%$ increase (not statistically significant) in the total concentration of cyto- chrome P-450, while there was no increase for the other solven'ts.

The SDS-polyacrylamide gel electrophoresis of liver microsomes revealed no significant changes in the different forms of cytochrome $\mathrm{P}-450$ after exposure to $\mathrm{n}$-hexane, methyl ethyl ketone or methyl-

Table 1. Effects of n-hexane, xylene, methyl ethyl ketone, and methylchloroform inhalation on rat liver - Mean \pm SD.

\begin{tabular}{|c|c|c|c|}
\hline \multirow{2}{*}{ Substance a } & \multirow{2}{*}{ Liver weight $(g)$} & Liver weight & nmoles $P-450$ \\
\hline & & Body weigh & mg microsomal protein \\
\hline $\begin{array}{l}\text { n-Hexane } \\
\text { Xylene } \\
\text { Control }\end{array}$ & $\begin{array}{l}11.3 \pm 0.8 \\
12.2 \pm 0.4 ! \\
11.2 \pm 0.1\end{array}$ & $\begin{array}{l}0.028 \pm 0.0007 \\
0.031 \pm 0.0005 \\
0.027 \pm 0.0004\end{array}$ & $\begin{array}{l}0.57 \pm 0.13 \\
0.70 \pm 0.05 \\
0.59 \pm 0.12\end{array}$ \\
\hline $\begin{array}{l}\text { Methyl ethyl ketone } \\
\text { Methylchloroform } \\
\text { Control }\end{array}$ & $\begin{array}{l}11.5 \pm 0.5 \\
11.7 \pm 0.7 \\
10.2 \pm 0.5\end{array}$ & $\begin{array}{l}0.029 \pm 0.00081 \\
0.029 \pm 0.00141 \\
0.025 \pm 0.005\end{array}$ & $\begin{array}{l}0.63 \pm 0.05 \\
0.56 \pm 0.07 \\
0.59 \pm 0.04\end{array}$ \\
\hline
\end{tabular}

a The experimental rats were exposed to $900 \mathrm{ppm}$ of $\mathrm{n}$-hexane $\left(3,240 \mathrm{mg} / \mathrm{m}^{3}\right), 600 \mathrm{ppm}$ of $x y l e n e\left(2,675 \mathrm{mg} / \mathrm{m}^{3}\right)$, $800 \mathrm{ppm}$ of methyl ethyl ketone $\left(2,345 \mathrm{mg} / \mathrm{m}^{3}\right)$ or $800 \mathrm{ppm}$ of methylchloroform $\left(4,345 \mathrm{mg} / \mathrm{m}^{3}\right)$ tor $6 \mathrm{~h}$ a $\mathrm{day}, 5 \mathrm{~d}$ a week, during four weeks. The controls were exposed to circulating air only.

1) Significantly different from control ( $\mathrm{p}<0.05, \mathrm{~N}=4)$.

Table 2. Hydroxylation of biphenyl and benzo(a)pyrene in rat liver microsomes after exposure to n-hexane, xylene, methyl ethyl ketone and methylchloroform - Mean $\pm \mathrm{SD}$.

\begin{tabular}{|c|c|c|c|c|c|c|c|c|c|}
\hline \multirow[t]{2}{*}{ Substance $^{a}$} & \multicolumn{3}{|c|}{$\begin{array}{l}\text { Biphenyl (pmol meta- } \\
\left.\text { bolite } \cdot \mathrm{mg}_{\text {protein }}^{-1} \cdot \mathrm{min}^{-1}\right)\end{array}$} & \multicolumn{6}{|c|}{$\begin{array}{l}\text { Benzo(a)pyrene } \\
\left(\text { pmol metabolite } \cdot \mathrm{mg} \text { protein-1 } \cdot \mathrm{min}^{-1}\right)\end{array}$} \\
\hline & $2-\mathrm{OH}$ & $3-\mathrm{OH}$ & $4-\mathrm{OH}$ & 9,10-Diol & 4,5-Diol & 7,8-Diol & Phenol I & Phenol II & Quinones \\
\hline $\begin{array}{l}\text { n-Hexane } \\
\text { Xylene } \\
\text { Control }\end{array}$ & $\begin{array}{l}66 \pm 7 \\
96 \pm 6 c \\
53 \pm 10\end{array}$ & $\begin{array}{l}<30 \\
33 \pm 2 \\
<30\end{array}$ & $\begin{array}{l}1,210 \pm 210 \\
1,380 \pm 50^{\circ} \\
1,050 \pm 260\end{array}$ & $\begin{array}{l}31 \pm 12 \\
45 \pm 8 \\
29 \pm 2\end{array}$ & $\begin{array}{l}25 \pm 4 \\
84 \pm 8 \\
17 \pm 8\end{array}$ & $\begin{array}{l}18 \pm 8 \\
20 \pm 2 \\
21 \pm 6\end{array}$ & $\begin{array}{l}25 \pm 11 \\
57 \pm 14 \\
47 \pm 39\end{array}$ & $\begin{array}{l}336 \pm 59 \\
438 \pm 58 \\
367 \pm 59\end{array}$ & $\begin{array}{l}30 \pm 6 \\
34 \pm 4 \\
20 \pm 7\end{array}$ \\
\hline $\begin{array}{l}\text { Methyl ethyl ketone } \\
\text { Methylchloroform } \\
\text { Control }\end{array}$ & $\begin{array}{l}30 \pm 5 \\
22 \pm 5 \\
32 \pm 6\end{array}$ & $\begin{array}{l}32 \pm 12 \\
<30 \\
<30\end{array}$ & $\begin{aligned} 1,030 & \pm 165 \\
760 & \pm 155 c \\
1,030 & \pm 70\end{aligned}$ & $\begin{array}{l}23 \pm 2^{c} \\
19 \pm 6 \\
35 \pm 4\end{array}$ & $\begin{array}{l}47 \pm 8 \\
36 \pm 6 \\
41 \pm 8\end{array}$ & $\begin{array}{l}17 \pm 3 \\
13 \pm 4 \\
16 \pm 3\end{array}$ & $\begin{array}{r}110 \pm 25 \\
52 \pm 12 \\
76 \pm 23\end{array}$ & $\begin{array}{l}284 \pm 44^{\prime \prime} \\
252 \pm 62^{\circ} \\
384 \pm 49^{\circ}\end{array}$ & $\begin{array}{l}22 \pm 9 \\
14 \pm 3 \\
20 \pm 8\end{array}$ \\
\hline
\end{tabular}

a The experimental rats were exposed to $900 \mathrm{ppm}$ of $\mathrm{n}$-hexane $\left(3,240 \mathrm{mg} / \mathrm{m}^{3}\right), 600 \mathrm{ppm}$ of $x y l e n e\left(2,675 \mathrm{mg} / \mathrm{m}^{3}\right), 800$

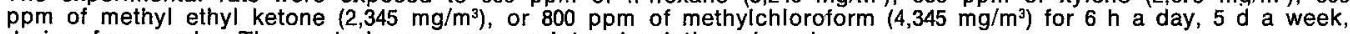
during four weeks. The controls were exposed to circulating air only.

" Abbreviations: 4,5-diol: trans-4,5-dihydroxy-4,5-dihydrobenzo(a)pyrene; 7,8-diol: trans-7,8-dihydroxy-7,8-dihydrobenzo(a)pyrene; 9,10-diol: trans-9,10-dihydroxy-9,10-dihydrobenzo(a)pyrene.

c Significantly different from control ( $\mathrm{p}<0.05, N=4)$.

Table 3. Metabolism of 4-androstene-3,17-dione and $5 \alpha$-androstane- $3 \alpha, 17 \beta$-diol in rat liver microsomes after exposure to n-hexane, xylene, methyl ethyl ketone and methylchloroform - Mean \pm SD.

\begin{tabular}{|c|c|c|c|c|c|c|c|c|}
\hline \multirow{2}{*}{ Substance ${ }^{a}$} & \multicolumn{3}{|c|}{$\begin{array}{l}\text { 4-androstene-3,17-dione } \\
\left.\text { (nmol metabolite } \cdot \mathrm{mg} \text { protein }{ }^{-1} \cdot \mathrm{min}^{-1}\right)\end{array}$} & \multicolumn{5}{|c|}{$\begin{array}{l}5 \alpha \text {-androstane- } 3 a, 17 \beta \text {-diol } \\
\text { (nmol metabolite } \cdot \mathrm{mg} \text { protein }{ }^{-1} \cdot \mathrm{min}^{-1} \text { ) }\end{array}$} \\
\hline & $7 \alpha-\mathrm{OH}$ & $6 \beta-\mathrm{OH}$ & $16-\mathrm{OH}$ & $\begin{array}{l}2 a, 3 a, 17 \beta- \\
\text { triol }\end{array}$ & $\begin{array}{l}2 \beta, 3 \alpha, 17 \beta- \\
\text { triol }\end{array}$ & $\begin{array}{l}3 a, 7 \alpha, 17 \beta= \\
\text { triol }\end{array}$ & $\begin{array}{l}3 \alpha, 7 \beta, 17 \beta- \\
\text { triol }\end{array}$ & $\begin{array}{l}3 a, 17 \beta, 18- \\
\text { triol }\end{array}$ \\
\hline $\begin{array}{l}\text { n-Hexane } \\
\text { Xylene } \\
\text { Control }\end{array}$ & $\begin{array}{l}0.22 \pm 0.03 \\
0.26 \pm 0.07 \\
0.20 \pm 0.03\end{array}$ & $\begin{array}{l}1.40 \pm 0.10 \\
1.42 \pm 0.19 \\
1.22 \pm 0.18\end{array}$ & $\begin{array}{l}0.80 \pm 0.11 \\
1.33 \pm 0.18 b \\
0.84 \pm 0.07\end{array}$ & $\begin{array}{l}0.71 \pm 0.05 \\
0.54 \pm 0.03^{h} \\
0.83 \pm 0.11\end{array}$ & $\begin{array}{l}0.25 \pm 0.05 \\
0.22 \pm 0.05 \\
0.22 \pm 0.04\end{array}$ & $\begin{array}{l}0.25 \pm 0.04 \\
0.24 \pm 0.02 \\
0.27 \pm 0.03\end{array}$ & $\begin{array}{l}0.12 \pm 0.08 \\
0.13 \pm 0.01 \\
0.11 \pm 0.01\end{array}$ & $\begin{array}{l}0.30 \pm 0.01 \\
0.35 \pm 0.01^{b} \\
0.30 \pm 0.02\end{array}$ \\
\hline $\begin{array}{l}\text { Methyl ethyl ketone } \\
\text { Methylchloroform } \\
\text { Control }\end{array}$ & $\begin{array}{l}0.24 \pm 0.01^{b} \\
0.18 \pm 0.01 \\
0.17 \pm 0.03\end{array}$ & $\begin{array}{l}1.06 \pm 0.06^{b} \\
0.82 \pm 0.13^{3} \\
1.32 \pm 0.19\end{array}$ & $\begin{array}{l}0.68 \pm 0.07^{i} \\
0.45 \pm 0.03^{b} \\
0.85 \pm 0.10\end{array}$ & $\begin{array}{l}0.90 \pm 0.18 \\
0.75 \pm 0.03 \\
0.78 \pm 0.12\end{array}$ & $\begin{array}{l}0.45 \pm 0.09 \\
0.28 \pm 0.06 \\
0.28 \pm 0.06\end{array}$ & $\begin{array}{l}0.36 \pm 0.06 \\
0.30 \pm 0.02 \\
0.36 \pm 0.03\end{array}$ & $\begin{array}{l}0.14 \pm 0.02 \\
0.10 \pm 0.02^{b} \\
0.14 \pm 0.02\end{array}$ & $\begin{array}{l}0.38 \pm 0.07 \\
0.29 \pm 0.06 \\
0.34 \pm 0.01\end{array}$ \\
\hline
\end{tabular}

a The experimental rats were exposed to $900 \mathrm{ppm}$ of $\mathrm{n}$-hexane $\left(3,240 \mathrm{mg} / \mathrm{m}^{3}\right), 600 \mathrm{ppm}$ of $x y /$ ene $\left(2,675 \mathrm{mg} / \mathrm{m}^{3}\right)$, 800 ppm of methyl ethyl ketone $\left(2,345 \mathrm{mg} / \mathrm{m}^{3}\right)$ or $800 \mathrm{ppm}$ of methylchloroform $\left(4,345 \mathrm{mg} / \mathrm{m}^{3}\right)$ for $6 \mathrm{~h}$ a day, $5 \mathrm{~d}$ a week, during four weeks. The controls were exposed to circulating air only.

b Significantly different from control ( $\mathrm{p}<0.05, \mathrm{~N}=4)$. 
chloroform, while increases in two forms were noted after exposure to xylene. Relative quantitation of these forms by densitometric scanning revealed a $100 \%$ increase in RLvMc P-450 50 and a $35 \%$ increase in RLvMc P-450 54 .

Following exposure to xylene, significant increases were noted in the in vitro liver microsomal metabolism of biphenyl to 2- and 4-hydroxybiphenyl (table 2). nHexane and methyl ethyl ketone had no significant effects, while methylchloroform reduced the formation of 2- and 4-hydroxybiphenyl. The formation of 4,5-dihydroxy-4,5-dihydrobenzo(a)pyrene from benzo(a)pyrene was selectively increased five times after exposure to xylene, and the formation of 9,10-dihydroxy-9,10dihydrobenzo(a)pyrene was increased by $50 \%$ (table 2). Exposure to methyl ethyl ketone and methylchloroform significantly decreased the formation of both 9,10-dihydroxy-9,10-dihydrobenzo(a)pyrene and phenols in phenol fraction II. Exposure to n-hexane did not affect the liver microsomal metabolism of benzo(a)pyrene.

The effects of solvent exposure on the liver microsomal metabolism of 4-androstene-3,17-dione and $5 \alpha$-androstane-3 $\alpha$, $17 \beta$-diol are shown in table 3 . The formation of 16-hydroxylated androstenedione metabolites increased $60 \%$ following exposure to xylene. This phenomenon was mainly due to an increased formation of 16-ketotestosterone, as demonstrated by gas chromatography/mass spectrometry. Exposure to methyl ethyl ketone increased the formation of $7 \alpha$-hydroxyandrostenedione but decreased the formation of both $6 \beta$-hydroxyandrostenedione and 16-hydroxyandrostenedione. Exposure to methylchloroform also decreased the formation of the two latter metabolites. No effects were observed following the exposure to n-hexane.

Exposure to xylene increased the in vitro liver microsomal formation of $5 \alpha$-androstane-3 $\alpha, 7 \beta, 17 \beta$-triol and $5 \alpha$-androstane$3 \alpha, 17 \beta, 18$-triol and decreased the formation of $5 \alpha$-androstane- $2 \alpha, 3 \alpha, 17 \beta$-triol from $5 \alpha$-androstane- $3 \alpha, 17 \beta$-diol. Methyl ethyl ketone increased the formation of $5 \alpha$ androstane- $2 \beta, 3 \alpha, 17 \beta$-triol, while methylchloroform reduced the formation of $5 \alpha$ androstane- $3 \alpha, 7 \beta, 17 \beta$-triol. No effects were observed following the exposure to n-hexane.

\section{Discussion}

The results of this study and another recent study by Savolainen et al (26) imply that aromatic hydrocarbon solvents such as xylene are potential inducing agents for cytochrome P-450 and cytochrome P-450dependent reactions in the liver. This assumption is also supported by the similar effects of toluene on cytochrome P-450 (results to be published). Methyl ethyl ketone and methylchloroform do not seem to influence the total amount of liver microsomal cytochrome P-450 significantly, but they tend to depress some cytochrome P 450 dependent reactions. Although nhexane did not influence either the liver microsomal cytochrome P-450 or any of the cytochrome P-450-mediated reactions investigated, an induction of cytochrome $\mathrm{P}-450$ has been reported after the exposure of mice to a higher dose during a short period of time (13). Similar results have also been reported with respect to the effects of methylchloroform on rats (10). These findings may suggest a dose-dependent influence of n-hexane and methylchloroform on cytochrome P-450, and they indicate the importance of the length of exposure. The inducing capacity of xylene may partly be due to the large uptake of xylene in comparison to the uptake of methylchloroform and aliphatic solvents $(1,29)$.

SDS-polyacrylamide gel electrophoresis revealed that xylene induced RLvMc P$450_{50}$ and RLvMc P-450 same cytochrome $P-450$ forms that are induced to the greatest extent by phenobarbital (31). Furthermore, both xylene and phenobarbital increased the formation of 2- and 4-hydroxybiphenyl. Phenobar'bital increased the formation of 4,5-dihydroxy-4,5-dihydrobenzo(a)pyrene more than tenfold (31), while xylene increased the formation of this metabolite fivefold. The metabolism of androstenedione and androstanediol was also affected in a similar manner following exposure to xylene or phenobarbital. These data strongly indicate that xylene is a phenobarbitallike inducer of liver microsomal cyto- 
chrome P-450 in the rat. Methyl ethyl ketone, methylchloroform, and n-hexane did not cause any detectable induction either in the total amount of liver microsomal cytochrome $\mathrm{P}-450$ or in the multiple forms, as demonstrated by SDS-polyacrylamide gel electrophoresis. No increases were detected in the formation of the different metabolites of biphenyl or benzo(a)pyrene. However, methyl ethyl ketone and methylchloroform reduced the metabolism of the two mentioned substrates to some extent.

Since cytochrome P-450 metabolizes endogenous su'bstrates such as steroids, an induction of liver microsomal cytochrome P-450 may cause endocrine disturbances $(22,24)$. Whether the increased in vitro formation of 16-hydroxy-androstenedione after xylene exposure or the decreased formation of the same metabolite after methyl ethyl ketone and methylchloroform exposure are relevant for the in vivo situation remains to be established. It may be noted that reproduction disturibances have been reported in men exposed to organic solvents (8).

The induction of hepatic cytochrome P-450 by xylene has several toxicological implications. An increased metabolism of xylene itself with an increased formation of $p$-tolualdehyde from $p$-xylene can lead to the destruction of lung microsomal cytochrome P-450 after transport of the metabolite to the lung, as proposed by Patel et al (23). The increased formation of 4,5-dihydroxy-4,5-dihydrobenzo(a)pyrene implies an accelerated formation of the mutagenic 4,5-epoxy-4,5-dihydrobenzo(a)pyrene (15). The toxicological importance of this metabolite may be questionable, however, in view of recent reports on the efficient deactivation of this compound by epoxide hydrase and glutathione-S-transferase $(11,34)$. In contrast further metabolism of 7,8-dihydroxy-7,8dihydrobenzo(a)pyrene can lead to the formation of the very potent carcinogen and mutagen 7,8-dihydroxy-9,10-epoxy7,8,9,10-tetrahydrobenzo(a)pyrene (15). When animals given phenobarbital are exposed to $n$-hexane, an increased formation of 2-hexanol occurs (9) and probably leads to an accelerated production of the neurotoxic metabolite 2,5-hexanedione.
The hepatotoxicity of trichloroethylene and the covalent binding of trichloroethylene metabolites to DNA (deoxyribonucleic acid) increase after pretreatment with phenobarbital (2). Since xylene is shown to be a phenobarbital-like inducer, it is reasonable to assume that synergistic toxic effects may occur upon simultaneous exposure to xylene and other solvents.

\section{Acknowledgments}

This study was supported by a grant from the Swedish Work Environment Health Fund. One of us (OGN) is grateful to the Norwegian Research Council for Science and the Humanities for a fellowship.

We wish to thank A Öhrström and L Eng for their skillful technical assistance. The analysis of androstenedione metalbolites by gas chromatography/mass spectrometry was kindly performed by $\mathrm{Dr} J$ Rafter at the Department of Medical Nutrition, Karolinska Institute.

\section{References}

1. Astrand I. Uptake of solvents in the blood and tissues of man: A review. Scand $j$ work environ health 1 (1975) 199-218.

2. Banerjee $\mathrm{S}$, Duuren $\mathrm{BL}$ van. Covalent binding of the carcinogen trichloroethylene to hepatic microsomal proteins and to exogenous DNA in vitro. Cancer res 38 (1978) 776-780.

3. Berg A, Gustafsson J-A. Regulation of hydroxylation of $5 \alpha$-androstane-3 $\alpha-17 \beta$-diol in liver miorosomes from male and female rats. J biol chem 248 (1973) 6559-6567.

4. Couri D, Abdel-Rahman MS, Hetland LB. Biotransformation of $n$-hexane and methyl $\mathrm{n}$-butyl ketone in guinea-pigs and mice. Am ind hyg assoc $j 39$ (1978) 295-300.

5. Dalvi RR, Hunter AL, Neal RA. Toxicological implications of the mixed function oxidase catalyzed metabolism of carbon disulphide. Chemio-biol interactions 10 (1975) $347-361$.

6. Dalvi RR, Poore RE, Neal RA. Studies of the metabolism of carbon disulphide by rat liver microsomes. Life sci 14 (1974) 17851796.

7. Einarsson $\mathrm{K}$, Gustafsson J- $\AA$, Stenberg $\AA$. Neonatal imprinting of liver microsomal hydroxylation and reduction of steroids. $\mathrm{J}$ biol chem 248 (1973) 4987-4997.

8. Eliasson RG. Analysis of semen. Environ health perspect 24 (1978) $81-85$.

9. Frommer U, UIlrich V, Orrenius S. Influence of inducers and inhibitors on the hydroxylation pattern of $n$-hexane in rat 
liver microsomes. FEBS lett 41 (1974) 1416.

10. Fuller GC, Olshan A, Puri SD, Lal H. Induction of hepatic drug metabolism in rats by methylchloroform inhalation. $J$ pharmacol exp ther 175 (1970) 311-317.

11. Gelboin HV, Selkirk JK, Yang SK, Wiebel FJ, Nemoto N. Benzo(a)pyrene metabolism by mixed function oxygenases, hydratases and glutathione-S-transferases: Analysis by high pressure liquid chromatography. In: Arias IM, Jakoby WB, ed. Glutathione, metabolism and function. Raven press, New York, NY, 1976, pp 339-356.

12. Haugen DA, Coon MJ. Properties of electrophoretically homogenous phenobarbitalinducible and $\beta$-naphthoflavone-inducible forms of liver microsomal cytochrome P-450. J biol chem 251 (1976) 7929-7939.

13. Kraemer A, Staudinger HJ, Ullrich V. Effect of n-hexane inhalation on the monoxygenase system in mice liver microsomes. Chemio-biol interactions 8 (1974) 11-18.

14. Laemmli UK. Cleavage of structural proteins during the assembly of the head of bacteriphage T 4 . Nature 227 (1970) 680685.

15. Levin W, Wook AW, Wislocki PG, Chang RL, Kapitulnik J, Ma'h HD, Yagi H, Jerina DM, Conney AH. Mutagenicity and carcinogenicity of benzo(a)pyrene and benzo(a)pyrene derivatives. In: T'so POP, Gelboin HV, ed. Polycyclic hydrocarbons and cancer. Vol 1. Academic Press, New York, NY, 1978, pp 189-202.

16. Lowry OH, Rosebrough NJ, Farr AL, Randall RJ. Protein measurement with the Folin phenol reagent. $J$ biol chem 193 (1951) 265-275.

17. Magos L, Butler H. Effects of phenobarbitone and starvation on hepatotoxicity in rats exposed to carbon disulphide vapors. $\mathrm{Br} \mathrm{j}$ ind med 29 (1972) 95-98.

18. Moslen MT, Reynolds ES, Szabo S. Enhancement of the metabolism and hepatotoxicity of trichloroethylene and perchloroethylene. Biochem pharmacol 26 (1977) $369-375$.

19. Nilsen OG, Toftgård $R$, Ingelman-Sundberg M, Gustafsson J-Â. Qualitative alterations of cytochrome P-450 in mouse liver microsomes after administration of acrylamide and methylamethacrylate. Acta pharmacol toxicol 42 (1978) $196-202$.

20. Norpoth $\mathrm{K}$, Witting U, Springorum M. Induction of microsomal enzymes in the rat liver by inhalation of hydrocarbon solvents. Int Arch Arbeitsmed 33 (1974) 315321.

21. Omura $T$, Sato $R$. The carbon monoxidebinding pigment of liver microsomes: I.
Evidence for its hemoprotein nature. $\mathrm{J}$ biol chem 239 (1964) 2370-2378.

22. Palmitter RD, Mulvihill ER. Estrogenic activity of the insecticide kepone on the chicken oviduct. Science 201 (1978) 356358.

23. Patel JM, Harper C, Drew RT. The biotransformation of p-xylene to a toxic aldehyde. Drug metab dispos 6 (1978) $368-374$.

24. Pekall DB. Effects of toxaphene on hepatic enzyme induction and circulating steroid levels in the rat. Environ health perspect 13 (1976) 117-120.

25. Rusch GM, Leong BKJ, Laskin S. Benzene metabolism. J toxicol environ health (1977): suppl 2, 23-36.

26. Savolainen $\mathrm{H}$, Vainio $\mathrm{H}$, Helojoki M, Elovaara $\mathrm{E}$. Biochemical and toxicological effects of short-term intermittent xylene inhalation exposure and combined ethanol intake. Arch toxicol 41 (1978) 195-205.

27. Schaumburg HH, Spencer PS. Environmental hydrocarbons produce degeneration in cat hypothalamus and optic tract. Science 199 (1978) 199-200.

28. Shah HC, Lal H. Effects of 1,1,1-trichloroethane administered by different routes and in different solvents on barbiturate hypnosis and metabolism in mice. $J$ toxicol environ health 1 (1976) 807-816.

29. Sedivec V, Flek J. The absorption, metabolism and excretion of xylenes in man. Int arch occup environ health 37 (1976) 205217.

30. Sipes IG, Krishna G, Gilette JR. Bioactivation of carbon tetrachloride, chloroform and bromotrichloromethane: Role of cytochrome P-450. Life sci 20 (1977) 1541-1548.

31. Toftgård $R$, Nilsen $O G$, Ingelman-Sundberg M, Gustafsson J-A. Correlation between changes in enzymatic activities and induction of different forms of rat liver microsomal cytochrome P-450 after phenobarbital, 3-methylcholanthrene and 16acyanopregnenolone treatment. Acta pharmacol toxicol 46 (1980) $353-361$.

32. Vainio H, Parkki MG, Marniemi J. Effects of aliphatic chlorohydrocarbons on drugmetabolizing enzymes in ralt liver in vivo. Xenobiotica 6 (1976) 599-604.

33. Woo Y-T, Argus MF, Arcos JC. Effect of mixed-function oxidase modifiers on metabolism and toxicity of the oncogen dioxane. Cancer res 38 (1978) 1621-1625.

34. Wood AW, Levin W, Lu AYH, Yagi $H$, Hernandez O, Jerina DM, Conney AH. Metabolism of benzo(a)pyrene and benzo(a)pyrene derivatives to mutagenic products by highly purified hepatic microsomal enzymes. J biol chem 251 (1976) $4882-4890$.

Received for publication: 11 August 1980 